\title{
Body condition score at calving affects systemic and hepatic transcriptome indicators of inflammation and nutrient metabolism in grazing dairy cows
}

\author{
H. Akbar, ${ }^{*}$ T. M. Grala, $\dagger$ M. Vailati Riboni, ${ }^{*}$ F. C. Cardoso, ${ }^{*}$ G. Verkerk, $\dagger$ J. McGowan, $\dagger$ K. Macdonald, $\dagger$

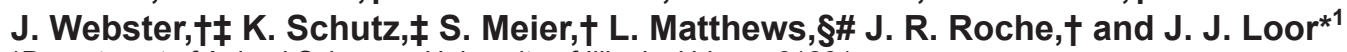 \\ *Department of Animal Sciences, University of Illinois, Urbana 61801 \\ †DairyNZ Limited, Private Bag 3221, Hamilton, New Zealand \\ $\ddagger$ AgResearch, Private Bag 3123, Hamilton 3240, New Zealand, \\ §Lindsay Matthews and Associates Research International, Viale Mario Torinese 38, Scerne di Pineto, Teramo 64025, Italy \\ \#University of Auckland, Private Bag 92019, Auckland 1142, New Zealand
}

\begin{abstract}
Calving body condition score (BCS) is an important determinant of early-lactation dry matter intake, milk yield, and disease incidence. The current study investigated the metabolic and molecular changes induced by the change in BCS. A group of cows of mixed age and breed were managed from the second half of the previous lactation to achieve mean group BCS (10-point scale) that were high (HBCS, 5.5; n $=20)$, medium (MBCS, 4.5; $\mathrm{n}=18)$, or low (LBCS, 3.5; $\mathrm{n}=19$ ). Blood was sampled at wk $-4,-3,-2,1,3,5$, and 6 relative to parturition to measure biomarkers of energy balance, inflammation, and liver function. Liver was biopsied on wk 1, 3, and 5 relative to parturition, and 10 cows per BCS group were used for transcript profiling via quantitative PCR. Cows in HBCS and MBCS produced more milk and had greater concentrations of nonesterified fatty acids and $\beta$-hydroxybutyrate postpartum than LBCS. Peak concentrations of nonesterified fatty acids and $\beta$-hydroxybutyrate and greater hepatic triacylglycerol concentrations were recorded in HBCS at wk 3. Consistent with blood biomarkers, HBCS and MBCS had greater expression of genes associated with fatty acid oxidation (CPT1A, ACOX1), ketogenesis (HMGCS2), and hepatokines (FGF21, ANGPTL4), whereas HBCS had the lowest expression of $A P O B$ (lipoprotein transport). Greater expression during early lactation of $B B O X 1$ in MBCS and LBCS suggested greater de novo carnitine synthesis. The greater BCS was associated with lower expression of growth hormone/insulin-like growth factor-1 signaling axis genes (GHR1A,IGF1, and IGFALS) and greater expression of gluconeogenic genes. These likely contributed to the higher milk production and greater gluconeogenesis. Despite greater serum haptoglobin
\end{abstract}

Received July 8, 2014.

Accepted November 3, 2014.

${ }^{1}$ Corresponding author: jloor@illinois.edu around calving, cows in HBCS and MBCS had greater blood albumin. Cows in MBCS, however, had a higher albumin:globulin ratio, probably indicating a less pronounced inflammatory status and better liver function. The marked decrease in expression of NFKB1, STAT3, $H P$, and $S A A 3$ coupled with the increase in $A L B$ on wk 3 in MBCS cows were consistent with blood measures. Overall, results suggest that the greater milk production of cows with higher calving BCS is associated with a proinflammatory response without negatively affecting expression of genes related to metabolism and the growth hormone/insulin-like growth factor-1 axis. Results highlight the sensitivity of indicators of metabolic health and inflammatory state to subtle changes in calving BCS and, collectively, indicate a suboptimal health status in cows calving at either BCS 3.5 or 5.5 relative to BCS 4.5.

Key words: body condition score, liver, grazing dairy cow, gene expression

\section{INTRODUCTION}

In dairy management systems, BCS is used as an indicator of body fat content and cow nutritional status. Cows should be managed to achieve appropriate BCS both pre- and postpartum to reduce threats to welfare, because BCS at calving may affect early lactation DMI, postcalving BCS loss, milk yield, cow immunity, and fertility (Roche et al., 2009). At calving, DMI and BCS are negatively correlated (Hayirli et al., 2002; Matthews et al., 2012), so that "fat" cows undergo a more pronounced and prolonged depression in DMI, leading to a deeper negative energy balance (NEB; Agenäs et al., 2003; Hayirli et al., 2002), an increase in lipomobilization, and a greater and persistent increase in blood NEFA (Dann et al., 2006). When hepatic uptake of NEFA exceeds the normal oxidative or export [as very low density lipoproteins (VLDL)] capacity, a greater production of ketone bodies, including BHBA (Drackley, 1999), will occur, leading to ketosis (Gillund 
et al. 2001). Furthermore, if the rate of esterification exceeds the rate of triacylglycerol (TAG) export via lipoproteins, fatty liver may develop (Drackley, 1999), thereby increasing susceptibility to other pathologies. Loss of BCS around parturition also is associated with the incidence of milk fever (Roche and Berry, 2006) and displaced abomasum (Bewley, 2008), 2 important metabolic disorders.

Although a recent review of the literature reported that not only overconditioned but also underconditioned dairy cows have a greater incidence of diseases than animals with a normal BCS (Roche et al., 2009), there are no reports on how calving BCS affects molecular signaling patterns in hepatic tissue during early lactation or their association with hepatic indicators of energy balance, liver function, and inflammation. It is likely that calving BCS affects the inflammatory response and liver function partly through alterations in gene expression. Thus, the objective of the present study was to profile the mRNA expression of key metabolic genes associated with fatty acid oxidation, ketogenesis, lipoprotein export, carnitine metabolism, gluconeogenesis, inflammation, and oxidative stress in liver biopsies harvested from cows with high (HBCS), medium (MBCS), and low (LBCS) BCS at calving (Roche et al., 2013). To better appreciate the links between BCS and systemic biomarkers, these data were complemented with liver TAG concentration and concentrations of blood biomarkers of energy balance, liver function, and inflammation.

\section{MATERIALS AND METHODS}

\section{Animals, Management, and Sampling}

Details of the project management were reported recently (Roche et al., 2013). Briefly, a group of 60 cows was allocated to 1 of 3 groups that underwent nutritional management through late lactation to achieve different BCS targets by the end of lactation [BCS targets were 5.0, 4.0, and 3.0, for HBCS, MBCS, and LBCS, respectively: 10-point system, where 1 is emaciated and 10 obese; Roche et al., 2004]. During the dry period, these cows were fed a ration that allowed for fetal growth and for the cows to gain 0.5 BCS unit before calving. The final targets for mean calving BCS were 5.5, 4.5, and 3.5 for the HBCS, MBCS, and LBCS groups, respectively.

Blood samples were obtained on $-4,-3$, and $-2 \mathrm{wk}$ precalving and $1,3,5$, and 6 wk postcalving by coccygeal venipuncture into evacuated tubes that contained heparin, EDTA, or no anticoagulant (Vacutainer, Becton Dickinson, Franklin Lakes, NJ). Samples containing heparin anticoagulant were placed immediately into iced water and then centrifuged within 60 min of collection to obtain plasma. Samples without anticoagulant were held at ambient temperature following collection for at least $4 \mathrm{~h}$ in order for serum to separate. Details of analyses are included in the supplemental materials (http://dx.doi.org/10.3168/jds.2014-8584). Briefly, serum was used to measure albumin (ALB), globulin (GLO, as the difference between total protein and albumin), creatinine, aspartate aminotransferase (AST), glutamate dehydrogenase (GDH), $\gamma$-glutamyl transferase (GGT), haptoglobin (HP), and serum amyloid A (SAA). Plasma was used to measure NEFA, BHBA, and glucose.

\section{Liver Biopsy}

Liver biopsy was attempted from all cows during the week before calving ( $-1 \mathrm{wk})$, and subsequently in 1,3 , and 5 wk. Briefly, the skin was shaved and disinfected, and the area through the skin and body wall was anesthetized with $7 \mathrm{~mL}$ of $2 \%$ lignocaine (Lopaine $2 \%$, lignocaine hydrochloride $20 \mathrm{mg} / \mathrm{mL}$, Ethical Agents, South Auckland, New Zealand). A stab incision was made through the skin in the right 11th intercostal space at the level of the greater trochanter through which a 12 -gauge $\times 20$-cm biopsy needle was inserted into the liver and approximately $1 \mathrm{~g}$ (wet weight) of liver tissue was collected. Samples were snap-frozen in liquid nitrogen and subsequently stored at $-80^{\circ} \mathrm{C}$.

\section{Liver TAG Analysis}

Liver TAG content was analyzed in biopsy samples $(-1,1,3$, and 5 wk) from the same 10 cows used for gene expression and blood biomarker analyses by modifying the procedure described in the Wako LabAssay Triglyceride Kit (Wako Chemicals USA Inc., Richmond, VA). Briefly, approximately $100 \mathrm{mg}$ of liver tissue was finely chopped using a sterile scalpel blade, and homogenized in $1 \mathrm{~mL}$ of $5 \%$ Triton-X100 in water. The homogenized tissue was slowly heated in a water bath (up to $80-100^{\circ} \mathrm{C}$ ) for 2 to $5 \mathrm{~min}$ or until the Triton X-100 appeared cloudy. After cooling the sample at room temperature, the heating process was repeated once to solubilize all TAG into solution. The samples were vortexed and centrifuged at 2,000 $\times g$ for $5 \mathrm{~min}$ at $4^{\circ} \mathrm{C}$ to remove any insoluble material. The supernatant was collected in sterile $1.5-\mathrm{mL}$ microfuge tubes and stored at $-80^{\circ} \mathrm{C}$. Approximately $50 \mu \mathrm{L}$ of sample was diluted 10-fold with distilled water before the TAG assay. The TAG analysis was performed using the standard procedure provided in the Wako LabAssay Triglyceride Kit. 


\section{RNA Extraction, Primer Design, and Real-Time Quantitative PCR}

These procedures are reported in detail in the supplemental material (http://dx.doi.org/10.3168/ jds.2014-8584). Briefly, complete sets of high-quality RNA were available from 10 cows per group at wk 1 , 3 , and 5 and were used for analysis of gene expression. Following TAG analyses, the samples from -1 wk were mistakenly left at $4^{\circ} \mathrm{C}$ and analyses of RNA revealed they were not suitable for gene expression analysis. In total, 25 key target genes were measured, associated with fatty acid oxidation, carnitine metabolism, growth hormone/IGF-1 axis, hepatokines, lipoprotein metabolism, ketogenesis, gluconeogenesis, inflammation, and oxidative stress (Table 1 and Supplemental Tables S1 to S4; http://dx.doi.org/10.3168/jds.2014-8584).

\section{Statistical Analysis}

After normalization with the geometric mean of the internal control genes, the quantitative PCR data from all treatments (HBCS, MBCS, and LBCS) were $\log _{2}$ transformed before statistical analysis. The TAG data were not normally distributed and were $\log _{10}$ transformed before statistical analysis. A repeated-measures model was fitted to gene expression, blood biomarkers, and hepatic TAG concentration data using the Proc
MIXED procedure in SAS (version 9.3; SAS Institute Inc., Cary, NC). The model consisted of week (w), BCS $(\mathbf{b})$, and $\mathrm{BCS} \times$ week $(\mathbf{b} \times \mathbf{w})$ as fixed effects, and cow as the random effect. An autoregressive covariate structure was used. All means were compared using the PDIFF statement of SAS.

\section{RESULTS}

\section{Milk Production}

Milk production was similar for HBCS and MBCS cows, and both groups had greater $(\mathrm{b}, P=0.01)$ milk production from 1 through 5 wk postpartum than LBCS cows (Figure 1).

\section{Blood Biomarkers}

Biomarkers of Energy Balance. We detected an interaction $(\mathrm{b} \times \mathrm{w}, P<0.01)$ for both NEFA and BHBA (Figure 2); concentrations of both parameters increased as early as 2 wk prepartum across all groups. The NEFA concentration was greater in HBCS and MBCS compared with LBCS cows at 2 wk prepartum through 6 wk postpartum. The pattern of BHBA followed a similar pattern to that of NEFA, but differences between treatments were not evident until wk 1 postpartum, when cows in HBCS had greater con-

Table 1. Symbol and description of the genes analyzed

\begin{tabular}{|c|c|}
\hline Symbol & Description \\
\hline$A C O X 1$ & Acyl-CoA oxidase 1, palmitoyl \\
\hline$A L B$ & Albumin \\
\hline ANGPTL4 & Angiopoietin-like 4 \\
\hline$A P O B$ & Apolipoprotein B \\
\hline$B B O X 1$ & Butyrobetaine (gamma), 2-oxoglutarate dioxygenase (gamma-butyrobetaine hydroxylase) 1 \\
\hline CPT1A & Carnitine palmitoyltransferase $1 \mathrm{~A}$ \\
\hline FGF21 & Fibroblast growth factor 21 \\
\hline$G A P D H$ & Glyceraldehyde-3-phosphate dehydrogenase \\
\hline GHR1A & Growth hormone receptor (GHR) $1 \mathrm{~A}$ \\
\hline$G P X 1$ & Glutathione peroxidase 1 \\
\hline$H M G C S 2$ & 3-Hydroxy-3-methylglutaryl-CoA synthase 2 \\
\hline$H P$ & Haptoglobin \\
\hline$I G F 1$ & Insulin-like growth factor 1 \\
\hline$I G F A L S$ & Insulin-like growth factor binding protein, acid labile subunit \\
\hline IGFBP3 & Insulin-like growth factor binding protein 3 \\
\hline$M T T P$ & Microsomal triglyceride transfer protein \\
\hline$N F K B 1$ & Nuclear factor of kappa light polypeptide gene enhancer in B-cells 1 \\
\hline$P C$ & Pyruvate carboxylase \\
\hline$P C K 1$ & Phosphoenolpyruvate carboxykinase 1 \\
\hline $\mathrm{PDK}_{4}$ & Pyruvate dehydrogenase kinase, isozyme 4 \\
\hline PPARA & Peroxisome proliferator-activated receptor alpha \\
\hline RPS9 & Ribosomal protein s9 \\
\hline$S A A 3$ & Serum amyloid A 3 \\
\hline$S L C 22 A 5$ & Solute carrier family 22 (organic cation/carnitine transporter), member 5 \\
\hline SOD1 & Superoxide dismutase 1 \\
\hline STAT3 & Signal transducer and activator of transcription 3 \\
\hline TMLHE & Trimethyllysine hydroxylase, epsilon \\
\hline$U X T$ & Ubiquitously expressed, prefoldin-like chaperone \\
\hline
\end{tabular}




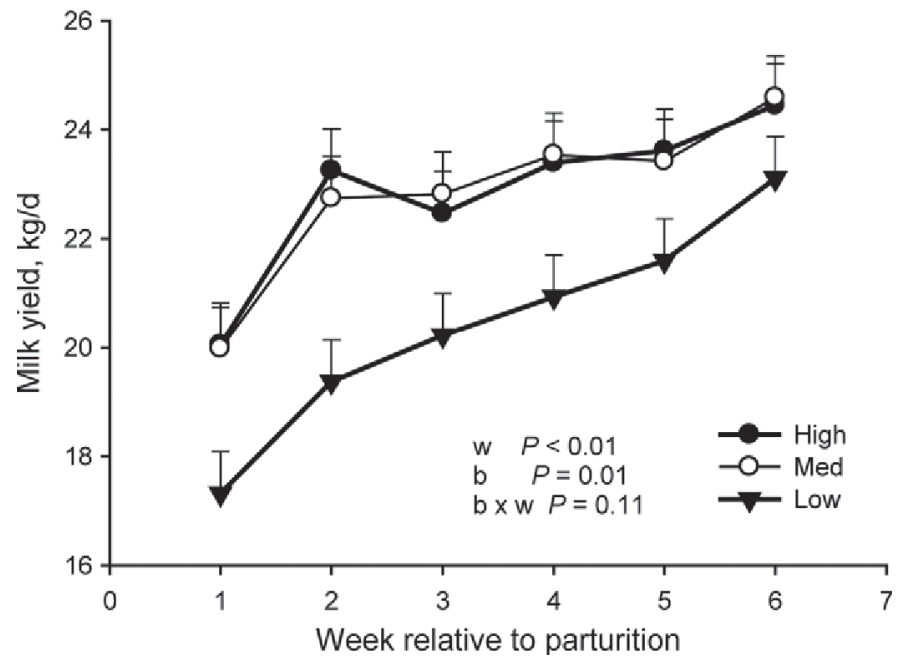

Figure 1. The effect of BCS at calving on milk production during the first 6 wk postcalving. Cows were managed during the dry period to maintain a high, low, or medium (Med) BCS until calving. The error bars represent SEM. The statistical effects of week (w), BCS (b), and BCS $\times$ week $(\mathrm{b} \times \mathrm{w})$ are indicated. Overall milk production was greater in HBCS and MBCS compared with LBCS.

centration than MBCS and LBCS, which were similar. Cows in MBCS had greater concentrations of BHBA from wk 3 until wk 6 compared with LBCS. Plasma concentration of glucose was not affected by treatment (Supplementary Figure S1; http://dx.doi.org/10.3168/ jds.2014-8584).

Biomarkers of Inflammation. We detected no interactions $(\mathrm{b} \times \mathrm{w}, P>0.05)$ for HP, SAA, GLO, ALB, or albumin:globulin ratio (AGR; Figure 3 and Supplementary Figure S2; http://dx.doi.org/10.3168/ jds.2014-8584). The concentrations of HP and SAA increased between wk 3 and 2 prepartum (Figure 3 ) and increased further postpartum (w, $P<0.01)$. In all groups, the concentration of GLO decreased (w, $P<$ 0.01 ) early after parturition with the nadir at 1 and 3 wk followed by a gradual increase in concentration by 5 wk postpartum (Figure 3). The concentration of ALB decreased (w, $P<0.01$ ) from -4 to -2 wk relative to parturition in all groups, but a postpartal increase (b, $P<0.01)$ was observed in HBCS and MBCS, whereas LBCS had comparatively lower concentrations of ALB during the study. We observed an overall increase (w, $P$ $<0.01$ ) in AGR from -2 wk to 3 wk relative to parturition. However, cows in MBCS had greater ( $b, P=0.05$ ) overall AGR compared with those in LBCS and HBCS (Supplementary Figure S2).

Biomarkers of Liver Function. We found no interaction $(\mathrm{b} \times \mathrm{w}, P>0.05)$ for AST, GGT, or GDH concentrations (Figure 4). However, in all groups, there was an overall increase $(w, P<0.01)$ in their concentrations between prepartum and postpartum. We found an
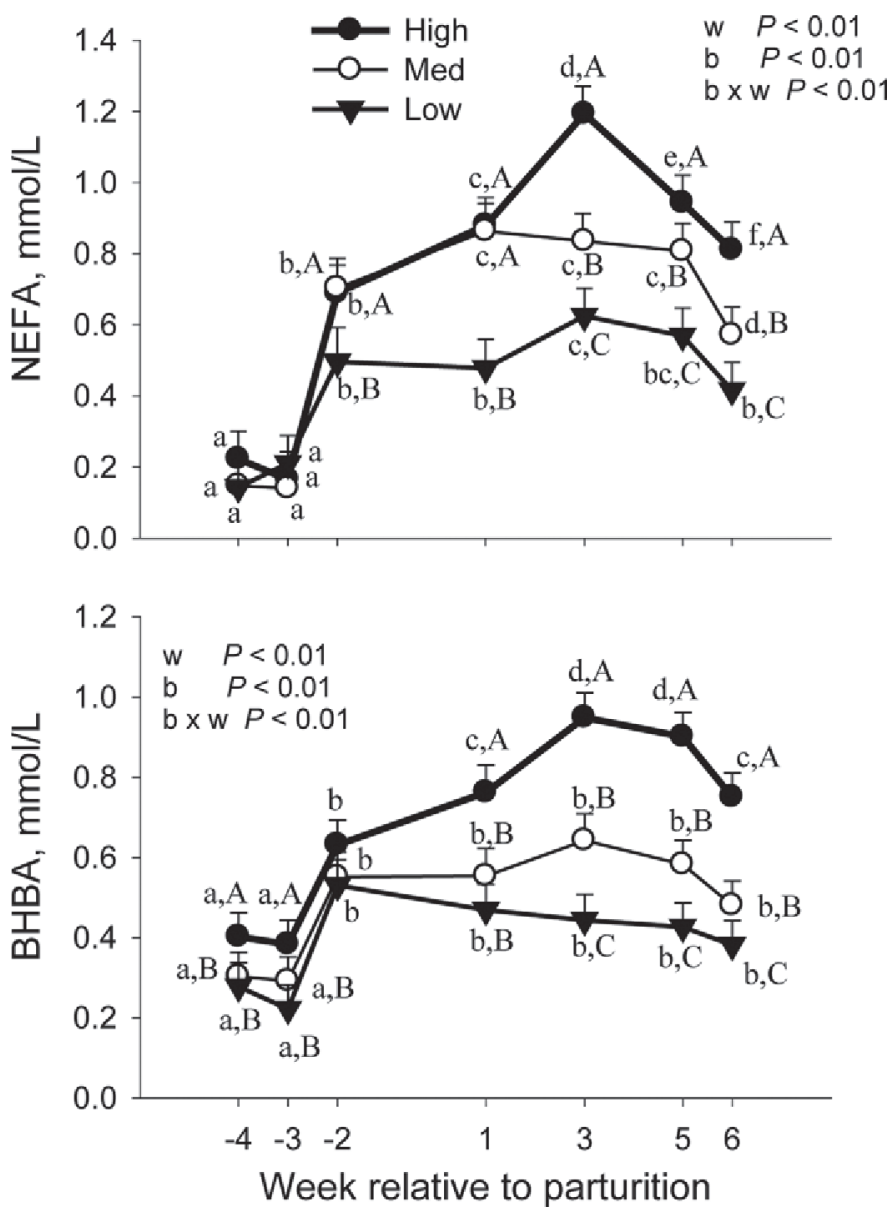

Figure 2. The effect of BCS at calving on the blood energy balance biomarkers NEFA and BHBA during the last 4 wk prepartum and the first 6 wk postpartum. Cows were managed during the dry period to maintain a high, low, or medium (Med) BCS until calving. The error bars represent SEM. The statistical effects of week (w), BCS (b), and $\mathrm{BCS} \times$ week $(\mathrm{b} \times \mathrm{w})$ are indicated. ${ }^{\mathrm{a}-\mathrm{c}} \mathrm{BCS} \times \mathrm{wk}(\mathrm{b} \times \mathrm{w}, P \leq 0.05)$ within a given BCS at different week; ${ }^{\mathrm{A} C} \mathrm{BCS} \times$ week $(\mathrm{b} \times \mathrm{w}, P \leq$ 0.05) among BCS at a given week.

interaction $(\mathrm{b} \times \mathrm{w}, P<0.01)$ for creatinine concentration, with greater concentrations of creatinine in MBCS and LBCS cows compared with HBCS in -4 and -2 wk. Between -2 and 3 wk around parturition, concentration decreased only for cows in MBCS and LBCS such that concentrations in 1 and 3 wk were similar for all groups. Between 3 and 5 wk postpartum, creatinine concentration decreased in all groups; this was more pronounced for cows in LBCS, such that cows in HBCS and MBCS had greater concentrations than LBCS at wk 5 (Figure 4 ).

\section{Hepatic TAG Concentration}

We detected an interaction $(\mathrm{b} \times \mathrm{w}, P<0.01)$ for the hepatic concentration of TAG (Figure 5). Although 

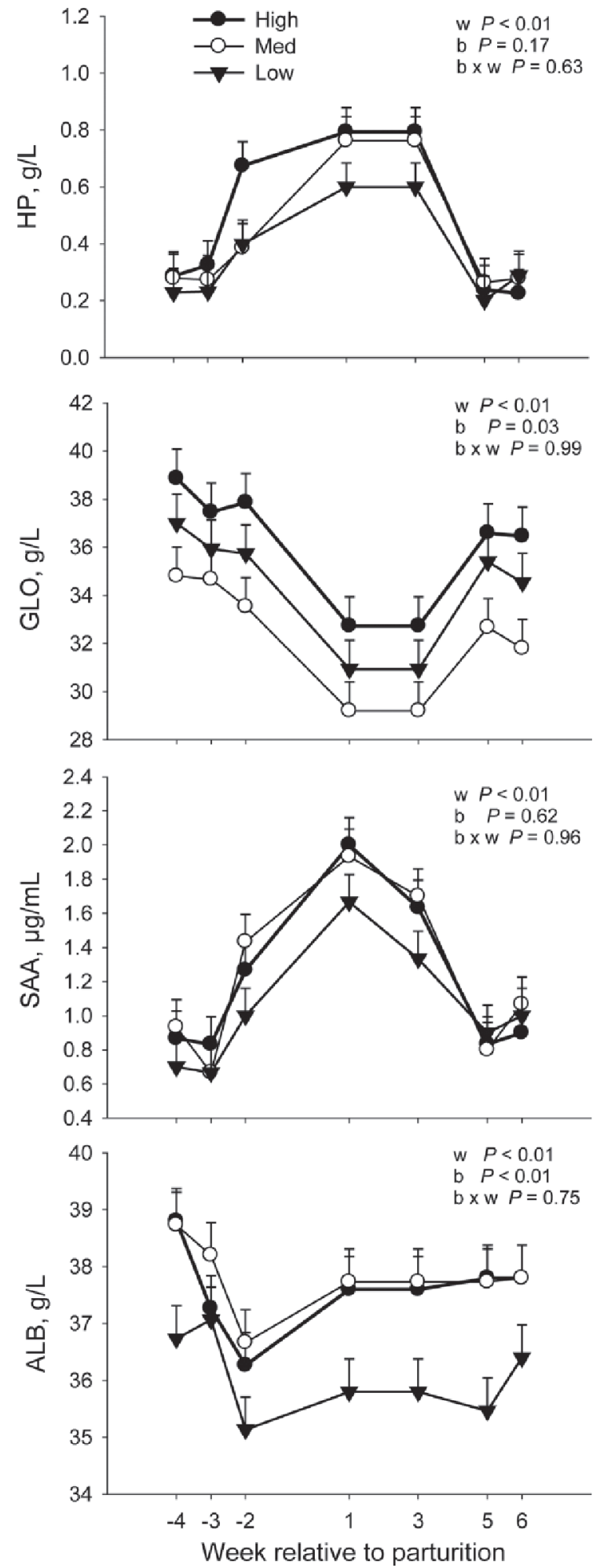

Figure 3. The effect of BCS at calving on the blood inflammation biomarkers haptoglobin (HP), globulin (GLO), serum amyloid A (SAA), and albumin (ALB), during the last 4 wk prepartum and the first 6 wh postpartum. Cows were managed during the dry period to maintain a high, low, or medium (Med) BCS until calving. The error bars represent SEM. The statistical effects of week (w), BCS (b), and $\mathrm{BCS} \times$ week $(\mathrm{b} \times \mathrm{w})$ are indicated. concentrations across BCS were similar prepartum, an increase occurred between -1 and $1 \mathrm{wk}$ for cows in the MBCS and HBCS groups, resulting in greater values compared with cows in LBCS. Cows in HBCS had a further increase in concentration by wk 3 , but concentration decreased in MBCS cows to values similar to those evident in LBCS. At 5 wk postpartum, the concentration of TAG had decreased in HBCS cows to levels similar to cows in MBCS, but in both groups, the concentration was greater than in LBCS.

\section{Hepatic Gene Expression}

Peroxisome Proliferator-Activated Receptor $\alpha$ Targets: Fatty Acid Oxidation, Ketogenesis, and Insulin-Like Growth Factor-I Binding Protein. We detected an interaction $(\mathrm{b} \times \mathrm{w}, P<0.05)$ for the expression of PPARA due to a decrease in HBCS cows between 1 and 3 wk followed by an increase at $5 \mathrm{wk}$ (Table 2). Among the peroxisome proliferator-activated receptor $\alpha(\mathbf{P P A R} \boldsymbol{\alpha})$ target genes evaluated, $\mathrm{b} \times \mathrm{W}$ effects $(P<0.01)$ were found for HMGCS2, ACOX1, and IGFBP1. The expression of HMGCS2 was greater in wk 1 and 3 for cows in HBCS compared with LBCS and MBCS. However, expression decreased by wk 5 in HBCS and MBCS cows, at which point expression did not differ among groups (Table 2). The expression of $A C O X 1$ was greater $(\mathrm{b} \times \mathrm{w}, P<0.01)$ in wk 3 and 5 in MBCS and HBCS cows. The overall temporal trend was for an increase ( $\mathrm{w}, P<0.01)$ in expression in HBCS and MBCS cows (at least by wk 3), whereas cows in LBCS had the same expression between 1 and 3 wk followed by a decrease at wk 5 . No interaction $(P=0.13)$ was found for the expression of CPT1A (Table 2). We did find an overall effect of BCS and week $(P<0.05)$ on $C P T 1 A$ such that expression was greater in MBCS and HBCS despite the fact that expression decreased from wk 1 to 5 . The pattern of expression of IGFBP 1 revealed that in wk 1 , cows in MBCS had greater $(\mathrm{b} \times$ $\mathrm{w}, P<0.05)$ expression than cows in LBCS. For both HBCS and MBCS, however, expression decreased $(\mathrm{b} \times$ $\mathrm{w}, P<0.05)$ by wk 3 and remained unchanged by wk 5 . Cows in LBCS had no difference in expression over time.

Synthesis and Secretion of VLDL. We observed interactions $(\mathrm{b} \times \mathrm{w}, P<0.05)$ for the expression of $M T T P$ and $A P O B$ (Table 2). In the case of MTTP, the interaction was primarily driven by the decrease in expression from wk 1 to 5 for cows in LBCS and MBCS compared with cows in HBCS. In contrast, the interaction effect for the expression of $A P O B$ was primarily due to the lower expression in HBCS at wk 1and 3, whereas by wk 5 , expression of $A P O B$ in HBCS cows increased and was similar across groups (Table 2). 

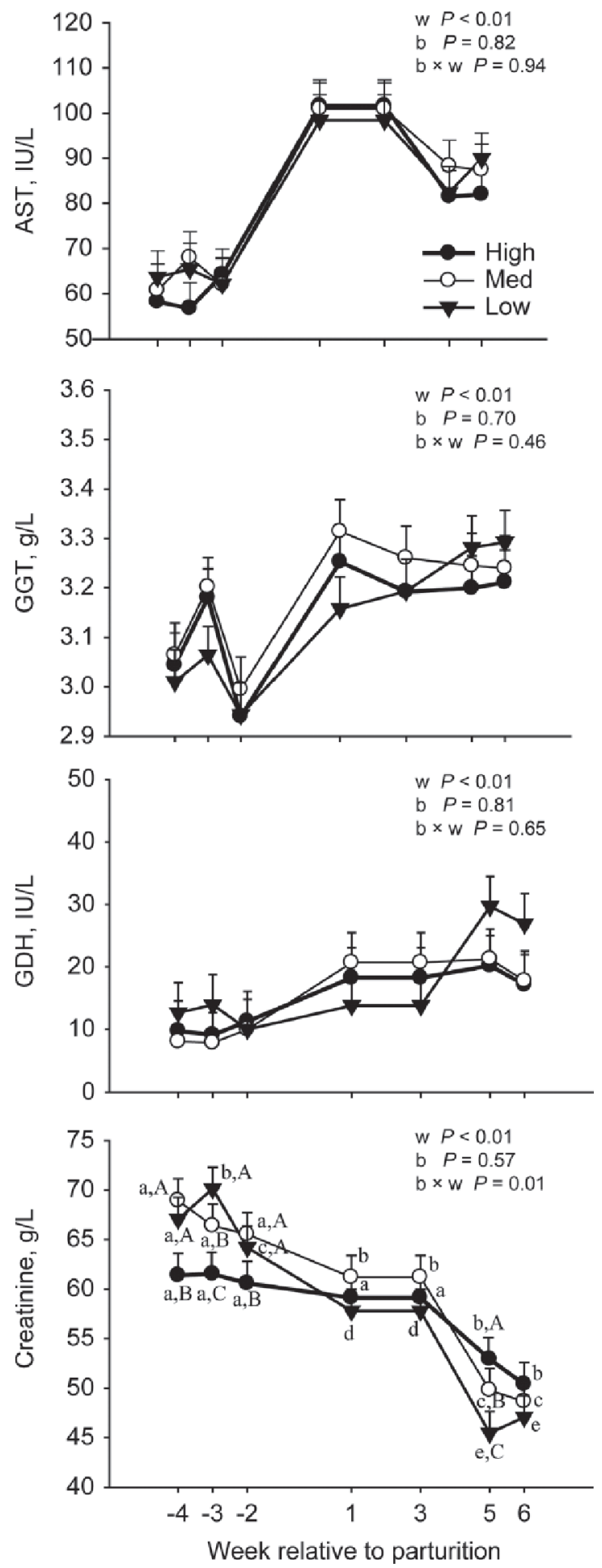

Figure 4. The effect of BCS at calving on blood liver function biomarkers serum aspartate transferase (AST), $\gamma$-glutamyltransferase (GGT), glutamate dehydrogenase (GDH), and creatinine (D) during the last $4 \mathrm{wk}$ prepartum and the first $6 \mathrm{wk}$ postpartum. Cows were managed during the dry period to maintain a high, low, or medium (Med) BCS until calving. The error bars represent SEM. The statistical effects of week $(w)$, BCS $(b)$, and BCS $\times$ week $(b \times w)$ are indicated. ${ }^{\mathrm{a} e} \mathrm{BCS} \times$ week $(\mathrm{b} \times \mathrm{w}, P \leq 0.05)$ within a given $\mathrm{BCS}$ at different week; ${ }^{\mathrm{A}-\mathrm{C}} \mathrm{BCS} \times$ week $(\mathrm{b} \times \mathrm{w}, P \leq 0.05)$ among $\mathrm{BCS}$ at a given week.
Growth Hormone/IGF-1 Axis. We detected an interaction $(\mathrm{b} \times \mathrm{w}, P<0.05)$ for the expression of $I G F 1$, IGFBP3, IGFALS, and GHR1A (Table 3). Expression of these genes increased over time (w, $P<0.01$ ), reaching a plateau between wk 3 and 5. Except for GHR1A (no changes from wk 3 to 5), differences among treatments were observed at 1 and 3 wk postpartum; by wk 5 , cows had similar expression independently of BCS (Table 3).

At wk 1, cows had similar expression of IGF1, whereas HBCS cows had greater IGFALS and GHR1A expression compared with MBCS. Cows in LBCS had intermediate expression of both genes. At wk 2, LBCS cows had greater expression of IGFBP3 compared with both HBCS and MBCS and greater IGF1 expression compared with HBCS. Cows in MBCS had an intermediate level of expression. For IGFALS, expression at wk 2 was highest in MBCS and lowest in HBCS cows.

Hepatokines. The expression of FGF21 and $A N G$ PTL 4 was affected by the interaction of BCS and wk (b $\times$ w, $P<0.01$; Table 3 ). The expression of both genes decreased over time (w, $P<0.01$ ) and was generally greater in HBCS compared with LBCS cows. In addition, cows in MBCS had greater expression of ANGPTL4 and FGF21 at wk 3 and 5 than LBCS cows. The expression of ANGPTL4 remained unchanged in cows in HBCS from wk 1 to 3 , unlike cows in LBCS and MBCS; however, ANGPTL4 expression in MBCS cows decreased more severely from wk 3 to 5 and had similar expression to MBCS at wk 5. In contrast, expression of FGF21 decreased in all cows from wk 1 to 3; however, in cows in MBCS and LBCS expression remained similar between wk 3 and 5 compared with a significant decrease in HBCS (Table 3).

Carnitine Synthesis and Uptake. The expression of BBOX1, TMLHE, and SLC22A5 was affected by the interaction of BCS and week (Table 4). Cows in HBCS had lower expression of $B B O X 1$ in wk 1 compared with MBCS and LBCS. In contrast, expression of TMLHE did not differ among groups in wk 1, but cows in HBCS had a decrease by wk 3, at which point expression was lower than in LBCS cows. It was noteworthy that the overall expression pattern of SLC22A5 changed over time (w, $P<0.01$ ) such that $S L C 22 A 5$ expression decreased gradually from wk 1 to 5 in cows in MBCS and LBCS; however, in HBCS cows, expression increased from wk 1 to 3 before decreasing at wk 5 .

Gluconeogenesis and Carbohydrate Metabolism. The expression of $P C, P C K 1$, and PDK4 was affected by the interaction of BCS and week $(\mathrm{b} \times \mathrm{w}$, $P<0.05 ;$ Table 4). We observed a gradual decrease in $P C$ expression over time, and cows in HBCS and MBCS had greater expression of $P C$ in wk 1 through 5 compared with LBCS. In addition, the expression of 


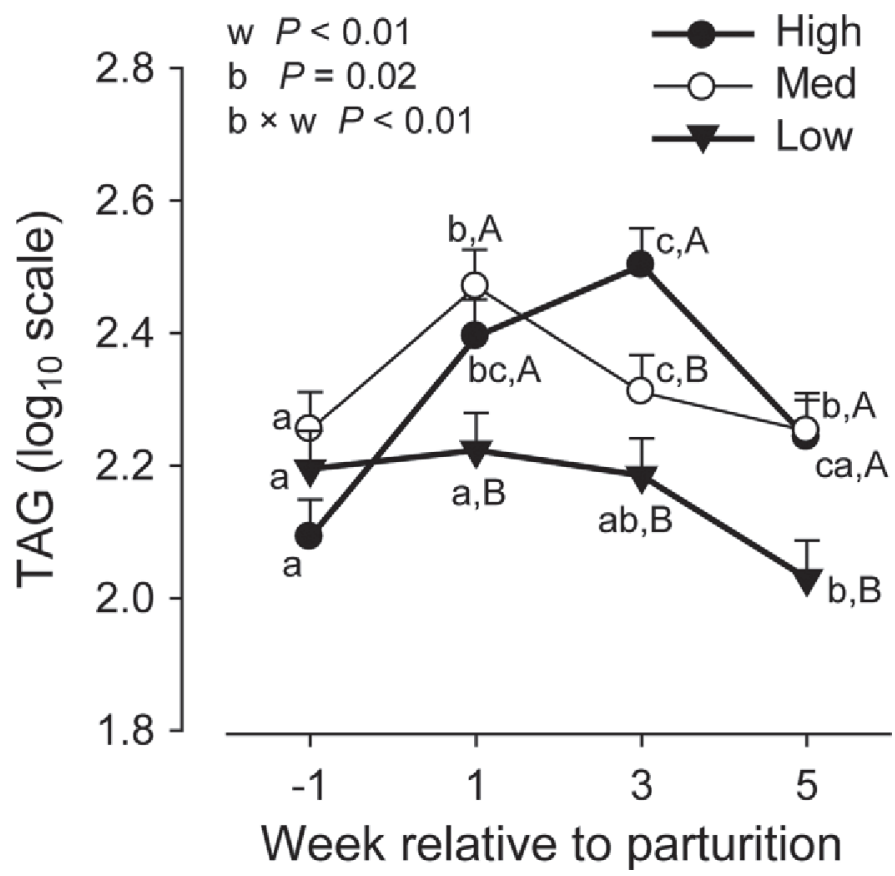

Figure 5. The effect of BCS at calving on concentration of triacylglycerol (TAG) in liver tissue in the last week prepartum and in wk 1,3 , and 5 postpartum. Cows were managed during the dry period to maintain a high, low, or medium (Med) BCS until calving. The error bars represent the SEM. The statistical effects of week (w), BCS (b), and BCS $\times$ week $(\mathrm{b} \times \mathrm{w})$ are indicated. ${ }^{\mathrm{a}-\mathrm{C}} \mathrm{BCS} \times$ week $(\mathrm{b} \times \mathrm{w}, P \leq$ $0.05)$ within a given BCS at different week; ${ }^{\mathrm{A}-\mathrm{C}} \mathrm{BCS} \times$ week $(\mathrm{b} \times \mathrm{w}, P$ $\leq 0.05)$ among BCS at a given week.

$P C$ at wk 3 was greater for cows in HBCS compared with MBCS. The expression of PDK4 also was greater in cows in HBCS compared with cows in LBCS at all weeks whereas, compared with MBCS, cows in HBCS had higher expression at wk 1 and 3 but a similar expression at wk 5 . In contrast to the effect of high BCS on $P C$ and $P D K 4$, the expression of PCK1 in HBCS cows increased $(\mathrm{b} \times \mathrm{w}, P<0.05)$ between wk 3 and 5 compared with LBCS cows, which followed the opposite trend. The expression of PCK1 for cows in MBCS increased from wk 1 to 3 and did not change from wk 3 to 5 .

Acute-Phase Proteins and Inflammation. In contrast to $A L B$, the recorded interaction $(\mathrm{b} \times \mathrm{w}, P$ $<0.05)$ in the expression of $H P, S A A 3, N F K B 1$, and STAT3 on wk 1 was caused by a greater change in expression for cows in MBCS compared with cows in HBCS (Table 5). Cows in LBCS had intermediate expression of these genes. The expression of $H P, S A A 3$, NFKB1, and STAT3 decreased $(\mathrm{b} \times \mathrm{w}, P<0.05)$ more markedly between wk 1 and 3 in MBCS and HBCS cows compared with LBCS. The interaction $(\mathrm{b} \times \mathrm{w}, P$ $<0.05)$ in wk 3 and 5 for the expression of $A L B$ was due to a lower expression for cows in HBCS compared with LBCS and MBCS.

Oxidative Stress. We detected no interaction for the expression of GPX1; however, there was an overall effect of time (w, $P<0.01)$ due to the increase in expression between wk 1 and 5 (Table 5). In contrast, we found an interaction $(\mathrm{b} \times \mathrm{w}, P<0.05)$ for expression of $S O D 1$ due to the lower expression in wk 1 for cows in MBCS and HBCS compared with LBCS. Expression increased for HBCS cows, peaking on wk 3, but, for cows in MBCS, peak expression occurred on wk 5. Cows in LBCS showed no change in expression over time.

\section{DISCUSSION}

The findings from the current study revealed that a higher BCS at calving benefits milk production, even though blood and liver tissue biomarkers indicate that those cows are in greater NEB during the first $5 \mathrm{wk}$ of lactation. Consistent with metabolic biomarkers, hepatic gene expression profiling revealed that a higher BCS at calving increases the capacity of the liver for fatty acid oxidation and ketogenesis. It was noteworthy that blood biomarkers of liver function were not affected by the high BCS at calving, despite the greater and more prolonged hepatic lipidosis. In addition, irrespective of calving BCS, all cows underwent a peripartal inflammatory response that was most evident after calving. Circulating protein concentrations and expression profiles of genes associated with inflammation were affected by changes in BCS and time relative to parturition. Although cows with a low BCS had the lowest concentrations of acute phase proteins (APP) around calving, their lower ALB (regardless of the greater $A L B$ mRNA expression) provided some evidence of liver dysfunction.

Overall, the collective measures of milk production, blood biomarkers of inflammation, blood metabolism biomarkers, and gene expression profiles suggest that cows calving at BCS 4.5 were in a more "optimal" health and productivity state than cows in either of the other 2 treatments. The results are, therefore, consistent with the recommendations by Roche et al. (2009) of 5.0 as an optimal calving BCS target (10-point system; 3.0 in 5 -point system) for grazing cows, as further supported by previous studies with confinement cows (Bernabucci et al., 2005; Lacetera et al., 2005). Although this is important information for producers to understand, of much greater significance is the demonstration that relatively subtle changes in calving BCS are associated with significant changes in hepatic metabolism and inflammatory state. 
Table 2. The effect of BCS at calving on postpartal expression of genes involved in fatty acid oxidation, ketogenesis, and peroxisome proliferatoractivated receptor $\alpha(\operatorname{PPAR} \alpha)$ signaling and lipoprotein synthesis $(\mathrm{n}=10 / \text { treatment per time point })^{1}$

\begin{tabular}{|c|c|c|c|c|c|c|c|c|}
\hline \multirow[b]{2}{*}{ Gene } & \multirow[b]{2}{*}{ Group } & \multicolumn{3}{|c|}{ Week relative to parturition } & \multirow[b]{2}{*}{$\mathrm{SEM}^{2}$} & \multicolumn{3}{|c|}{$P$-value } \\
\hline & & 1 & 3 & 5 & & $\mathrm{BCS}(\mathrm{b})$ & Week (w) & $\mathrm{b} \times \mathrm{w}$ \\
\hline \multicolumn{9}{|c|}{$\begin{array}{l}\text { FA oxidation, ketogenesis, } \\
\text { and PPAR } \alpha \text { signaling }\end{array}$} \\
\hline \multirow[t]{3}{*}{ PPARA } & HBCS & $1.10^{\mathrm{a}}$ & $0.98^{\mathrm{a}}$ & $1.30^{\mathrm{b}}$ & 0.23 & 0.65 & $<0.01$ & $<0.01$ \\
\hline & MBCS & 1.16 & 1.19 & 1.22 & & & & \\
\hline & LBCS & 1.26 & 1.20 & 1.28 & & & & \\
\hline \multirow[t]{3}{*}{$H M G C S 2$} & $\mathrm{HBCS}$ & $1.10^{\mathrm{a}, \mathrm{A}}$ & $1.43^{\mathrm{b}, \mathrm{A}}$ & $1.04^{\mathrm{c}}$ & 0.16 & 0.01 & $<0.01$ & $<0.01$ \\
\hline & MBCS & $0.61^{\mathrm{a}, \mathrm{B}}$ & $1.10^{\mathrm{b}, \mathrm{B}}$ & $0.93^{\mathrm{c}}$ & & & & \\
\hline & LBCS & $0.78^{\mathrm{C}}$ & $0.77^{\mathrm{C}}$ & 0.90 & & & & \\
\hline \multirow[t]{3}{*}{$A C O X 1$} & $\mathrm{HBCS}$ & $1.03^{\mathrm{a}}$ & $1.20^{\mathrm{b}, \mathrm{A}}$ & $1.29^{\mathrm{b}, \mathrm{A}}$ & 0.10 & $<0.01$ & 0.12 & $<0.01$ \\
\hline & MBCS & $0.95^{\mathrm{a}}$ & $1.27^{\mathrm{b}, \mathrm{A}}$ & $1.15^{\mathrm{c}, \mathrm{B}}$ & & & & \\
\hline & LBCS & 1.07 & $1.06^{\mathrm{B}}$ & $0.97^{\mathrm{C}}$ & & & & \\
\hline \multirow[t]{3}{*}{ CPT1A } & HBCS & 1.17 & 1.04 & 0.87 & 0.10 & 0.02 & $<0.01$ & 0.13 \\
\hline & MBCS & 1.17 & 0.98 & 0.81 & & & & \\
\hline & LBCS & 1.00 & 0.83 & 0.76 & & & & \\
\hline \multirow[t]{3}{*}{$I G F B P 1$} & HBCS & $1.28^{\mathrm{a}, \mathrm{AB}}$ & $0.84^{\mathrm{b}}$ & $0.89^{\mathrm{b}}$ & 0.39 & 0.99 & $<0.01$ & $<0.01$ \\
\hline & MBCS & $1.57^{\mathrm{a}, \mathrm{B}}$ & $0.78^{b}$ & $0.78^{\mathrm{b}}$ & & & & \\
\hline & $\mathrm{LBCS}$ & $0.99^{\mathrm{A}}$ & 1.03 & 0.93 & & & & \\
\hline \multicolumn{9}{|c|}{ Lipoprotein synthesis } \\
\hline \multirow[t]{3}{*}{$M T T P$} & $\mathrm{HBCS}$ & $1.28^{\mathrm{a}}$ & $1.06^{\mathrm{b}}$ & $1.18^{\mathrm{ab}, \mathrm{A}}$ & 0.17 & 0.9 & $<0.01$ & $<0.01$ \\
\hline & MBCS & $1.44^{\mathrm{a}}$ & $1.11^{\mathrm{b}}$ & $0.99^{\mathrm{c}, \mathrm{B}}$ & & & & \\
\hline & LBCS & $1.40^{\mathrm{a}}$ & $1.09^{\mathrm{b}}$ & $0.99^{\mathrm{c}, \mathrm{B}}$ & & & & \\
\hline \multirow[t]{3}{*}{$A P O B$} & HBCS & $0.80^{\mathrm{ab}, \mathrm{A}}$ & $0.76^{\mathrm{a}, \mathrm{A}}$ & $0.89^{\mathrm{b}}$ & 0.09 & 0.05 & $<0.01$ & 0.03 \\
\hline & MBCS & $0.92^{\mathrm{AB}}$ & $0.94^{\mathrm{ab}, \mathrm{B}}$ & $0.99^{\mathrm{b}}$ & & & & \\
\hline & LBCS & $0.88^{\mathrm{a}, \mathrm{AB}}$ & $0.96^{\mathrm{b}, \mathrm{B}}$ & $0.97^{\mathrm{b}}$ & & & & \\
\hline
\end{tabular}

${ }^{\mathrm{a}-\mathrm{c}}$ Interaction of $\mathrm{b} \times \mathrm{wk}(P \leq 0.05)$ within a BCS group in different weeks.

${ }^{\mathrm{A}-\mathrm{C}}$ Interaction of $\mathrm{b} \times$ wk $(P \leq 0.05)$ among $\mathrm{BCS}$ in a given week.

${ }^{1}$ Cows were managed during the dry period to maintain a high (HBCS), low (LBCS), or medium (MBCS) BCS until calving.

${ }^{2}$ Largest standard error of the mean is shown.

Table 3. The effect of BCS at calving on postpartal expression of genes involved in the growth hormone/IGF-1 signaling axis and liver-secreted hepatokines $(\mathrm{n}=10 / \text { treatment per time point })^{1}$

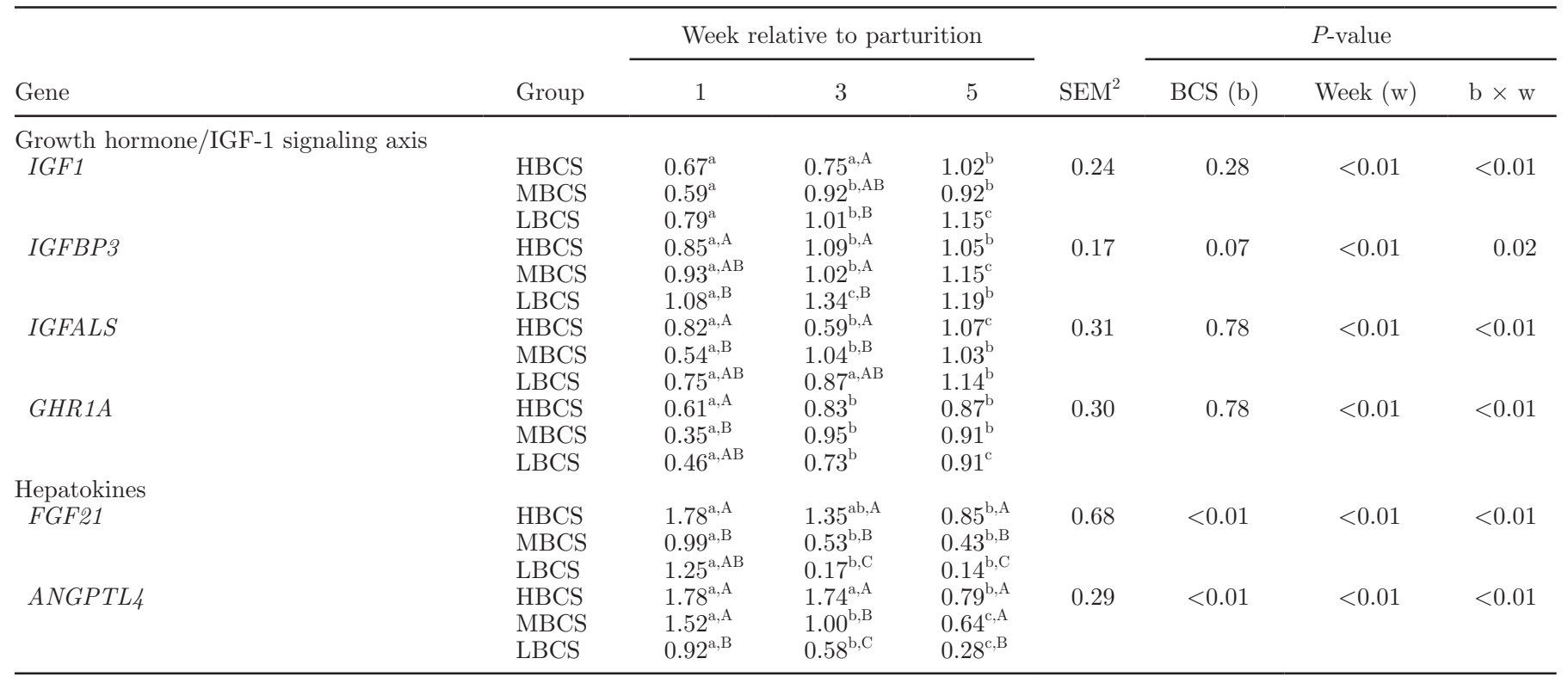

${ }^{\mathrm{a}-\mathrm{c}}$ Interaction of $\mathrm{b} \times$ wk $(P \leq 0.05)$ within a BCS group in different weeks.

${ }^{\mathrm{A}-\mathrm{C}}$ Interaction of $\mathrm{b} \times \mathrm{wk}(P \leq 0.05)$ among $\mathrm{BCS}$ in a given week.

${ }^{1}$ Cows were managed during the dry period to maintain a high (HBCS), low (LBCS), or medium (MBCS) BCS until calving.

${ }^{2}$ Largest standard error of the mean is shown. 
Table 4. The effect of BCS calving on postpartal expression of genes associated with carnitine synthesis and uptake and gluconeogenesis $(\mathrm{n}=$ $10 /$ treatment per time point) $)^{1}$

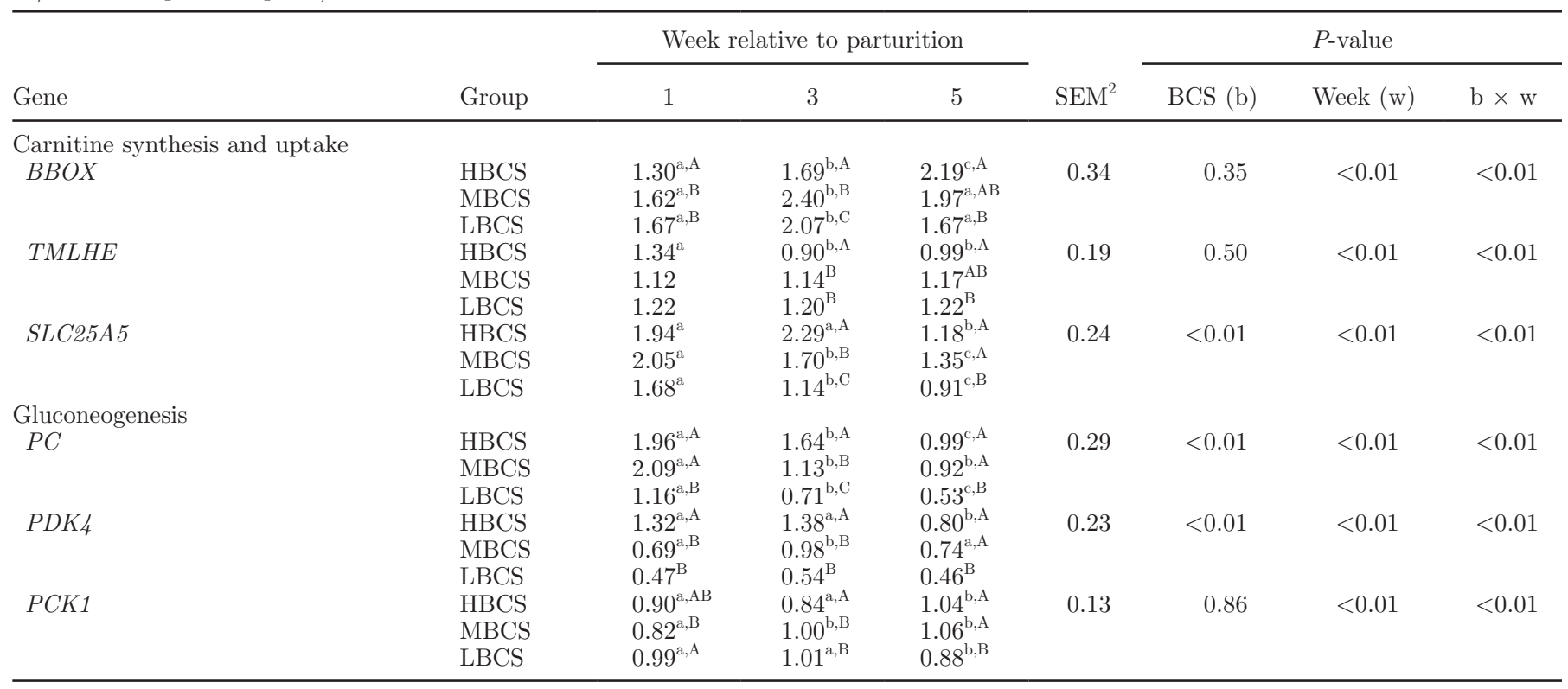

${ }^{\mathrm{a}-\mathrm{C}}$ Interaction of $\mathrm{b} \times$ wk $(P \leq 0.05)$ within a BCS group in different weeks.

${ }^{\mathrm{A}-\mathrm{C}}$ Interaction of $\mathrm{b} \times$ wk $(P \leq 0.05)$ among BCS in a given week.

${ }^{1}$ Cows were managed during the dry period to maintain a high (HBCS), low (LBCS), or medium (MBCS) BCS until calving.

${ }^{2}$ Largest standard error of the mean is shown.

Table 5. The effect of BCS at calving on postpartal expression of genes encoding acute-phase proteins, inflammation transcription regulators, and antioxidant enzymes $(\mathrm{n}=8 / \text { treatment per time point })^{1}$

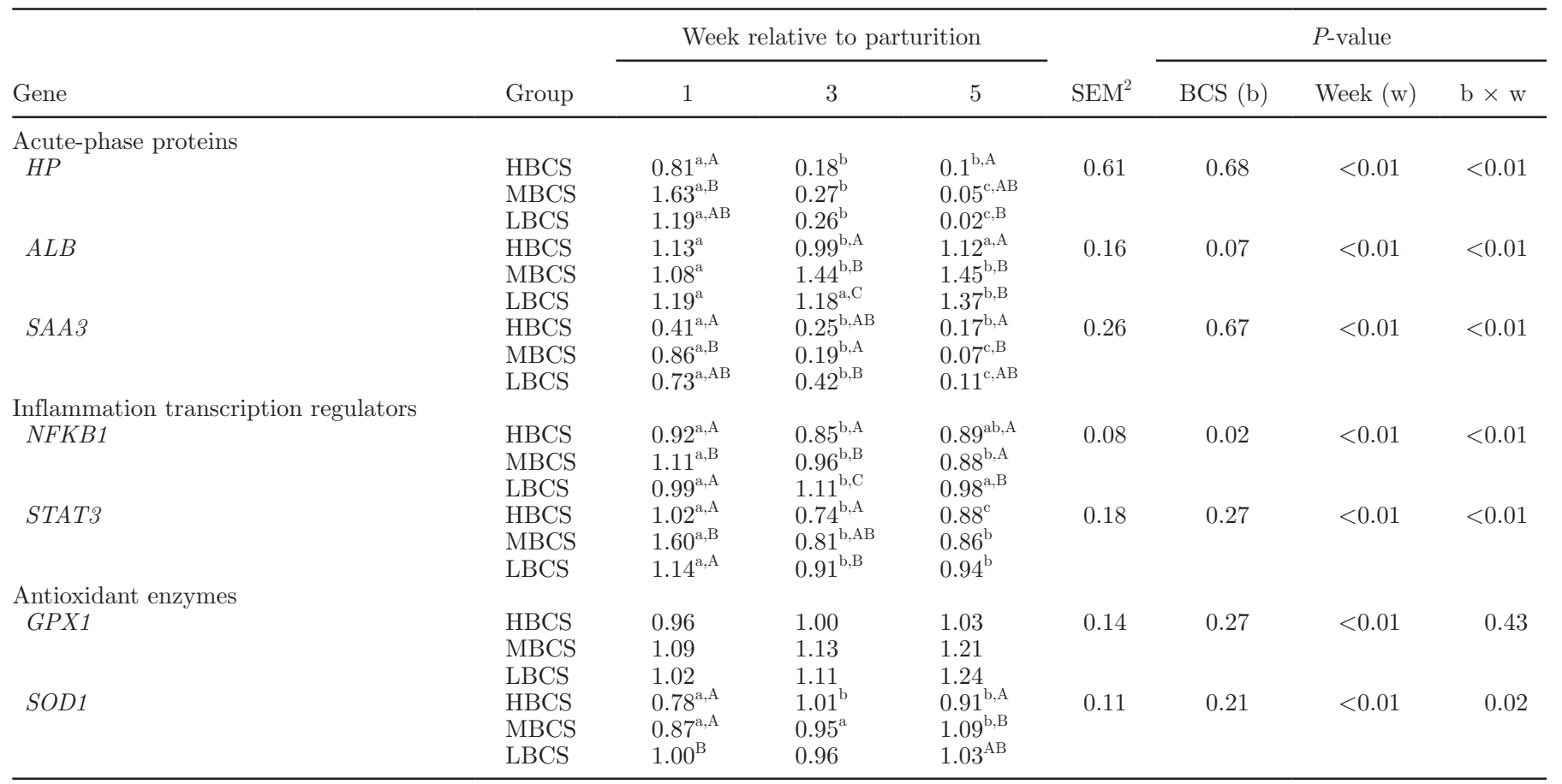

${ }^{\mathrm{a}-\mathrm{c}}$ Interaction of $\mathrm{b} \times \mathrm{wk}(P \leq 0.05)$ within a BCS group in different weeks.

${ }^{\mathrm{A}-\mathrm{C}}$ Interaction of $\mathrm{b} \times \mathrm{wk}(P \leq 0.05)$ among $\mathrm{BCS}$ in a given week.

${ }^{1}$ Cows were managed during the dry period to maintain a high (HBCS), low (LBCS), or medium (MBCS) BCS until calving.

${ }^{2}$ Largest standard error of the mean is shown. 


\section{BCS at Calving and Metabolic and Molecular Adaptations in Energy Metabolism}

General. The trend of milk production and the concentrations of NEFA and BHBA in blood postcalving in the HBCS and MBCS groups were indicative of a linear relationship between calving BCS and NEB, which is consistent with previous findings (Busato et al., 2002; Hayirli et al., 2002; Bernabucci et al., 2005). The overall associations between BCS and concentrations of the key plasma metabolites, where higher BCS links to higher BHBA and lower glucose concentrations whereas lower BCS links to lower NEFA and glucose concentrations, imply the existence of an optimum calving BCS to protect liver function. What is particularly interesting, however, is that these effects were evident over subtle changes in calving BCS (i.e., \pm 1.0 BCS units on a 10-point scale; approximately 0.5 BCS units on a 5 -point scale).

The effect of calving BCS on NEFA and BHBA blood levels is supported by the reported increased expression of genes associated with fatty acid oxidation and ketogenesis in both HBCS and MBCS cows relative to the LBCS cows, particularly during wk 1 and 3 postcalving. Despite the marked increase in the serum NEFA concentration as early as $2 \mathrm{wk}$ precalving in the LBCS cows, the liver TAG concentration remained unchanged throughout the study. Such a response agrees with previous reports in TMR-fed cows, in which nutritional management to avoid sudden and drastic changes in BCS around calving did not alter liver TAG significantly (Dann et al., 2006). Cows in the LBCS group maintained consistent BCS and consistent liver TAG concentrations after calving, so are unlikely to have experienced the hepatotoxic effects of lipid accumulation.

GH and IGF-1 Axis. The lower expression of GHR1A, IGFBP3, and IGFALS at wk 1 postpartum in cows in the MBCS group potentially indicates a more uncoupled somatotropic axis. The same could be said for HBCS animals at wk 3 postpartum (e.g., IGFBP3, $I G F A L S$, and IGF1). The greater plasma NEFA concentrations at wk 1 in cows in MBCS and HBCS relative to cows in LBCS support the idea that these cows had a more uncoupled somatotropic axis. Despite the lack of a difference in GHR1A expression from wk 3 onward, the greater expression of IGF1 and IGFBP3 in cows in LBCS, compared with cows in HBCS, indicates greater production and more stable transport of IGF1 (Boisclair et al., 2001). Insulin-like growth factor-1 binds to receptors to promote tissue growth (Nakae et al., 2001), which may limit the availability of nutrients for milk production; therefore, greater expression of these genes at wk 3 may contribute to the low milk production in cows in LBCS.
Fatty Acid Oxidation and Ketogenesis. In nonruminants, long-chain fatty acid (LCFA) oxidation and ketogenesis can be controlled at the transcription level (i.e., via changes in mRNA expression), the hormonal level (e.g., ratio of insulin to glucagon), or through the availability of substrate and carnitine (Eaton, 2002; Nakamura et al., 2014). These pathways are likely to operate in a similar manner in ruminants. From a molecular standpoint, greater expression of CPT1A and HMGCS2 at wk 1 and 3, and of $A C O X 1$ at wk 3 in the HBCS compared with the LBCS group reflect an increase in hepatic LCFA oxidation and ketogenesis in response to the higher influx of NEFA. This latter point is of particular interest because previous work in peripartal dairy cattle has provided evidence that peroxisomal LCFA oxidation provides an important pathway for hepatic processing of NEFA in the postcalving period (Grum et al., 1996). In the case of cows in HBCS and MBCS, the longitudinal response in ACOX1 and HMGCS2 and the patterns of circulating NEFA and BHBA indicate an early transcriptional response to increase the amount of enzymes, after which the availability of substrate and flux through the pathway might have driven the reactions. However, the data for liver TAG and the expression of genes involved in VLDL synthesis and secretion (MTTP and $A P O B$ ) indicate that molecular adaptations after calving were insufficient to prevent intracellular accumulation of TAG in response to high NEFA, particularly in HBCS cows.

The fatty acids taken up by hepatocytes can be activated by ACSL1 and transported into the mitochondria by $C P T 1 A$ and $C P T 2$ for $\beta$-oxidation. In the present study, the higher expression of CPT1A at 1 wk postpartum in MBCS and HBCS groups suggests greater transport of cytosolic LCFA to mitochondria for fatty acid oxidation, whereas the lower expression in the low BCS group supports the view that lower circulating NEFA concentrations in cows with low BCS reduced the hepatic uptake of NEFA and likely limited the demand for FA oxidation. The gradual decrease of CPT1A expression with time relative to parturition indicated an association with a lower concentration of mobilized NEFA and subsequent reduction in hepatic oxidation, as reported recently (Litherland et al., 2011).

Fatty Acid Oxidation and Carnitine Availability. In the context of CPT1A enzyme activity around calving, the role of hepatic carnitine availability for LCFA transport into mitochondria has received greater attention in recent years. Overall, the present results reveal a negative association between BCS and the level of expression of genes involved in endogenous carnitine synthesis (TMLHE and BBOX1), although at wk 3 postcalving we detected a positive association between BCS and hepatic ability to take up carnitine from cir- 
culation (SLC22A5). It has recently been demonstrated that TMLHE, BBOX1, and SLC22A5 are more highly expressed at $1 \mathrm{wk}$ postcalving than at $3 \mathrm{wk}$ prepartum (Schlegel et al., 2012).

The changes in expression over time observed in the present data would result in increased intracellular carnitine content, as reported by Schlegel et al. (2012), either from de novo synthesis (TMLHE, BBOX1) or from greater uptake (SLC22A5). The sustained upregulation of $B B O X 1$ in HBCS (from wk 1 to 5) indicates an important adaptation of the liver to the high NEFA influx. A previous study also reported sustained upregulation of $B B O X 1$ after calving, whereas expression of both TMLHE and SLC22A5 decreased between 1 and 5 wk postcalving (Schlegel et al., 2012). This suggests that hepatic synthesis of carnitine is an important adaptation of the tissue to cope with the influx of NEFA during the postcalving period.

The greater prepartal serum creatinine concentration for MBCS and LBCS compared with HBCS is suggestive of greater skeletal muscle breakdown. This could reflect mobilization of muscle tissue to meet energetic or other requirements due to their lower BCS status and, therefore, adipose reserves. As such, it is likely that availability of carnitine or amino acids needed for carnitine synthesis in liver (lysine and methionine), or both (Bremer, 1983), were increased. Such a requirement would partly explain the similar expression of SLC22A5 and TMLHE among groups at wk 1. Although the concentration of serum creatinine remained unchanged between wk 1 and 3 for all groups, the fact that TMLHE decreased markedly in the HBCS group while $S L C 22 A 5$ tended to increase at wk 3 may indicate that those cows relied more on muscle-derived carnitine uptake, whereas cows in MBCS and LBCS relied more on de novo synthesis via greater $B B O X 1$ expression. This hypothesis is supported by a greater concentration of liver carnitine after calving coupled with lower skeletal muscle carnitine (Carlson et al., 2007). Although data on amino acid uptake by liver around parturition are scarce, evidence suggests that, after calving, net liver removal of methionine and lysine (sources for carnitine synthesis) decreases in favor of their use by the mammary gland for milk protein synthesis (Doepel et al., 2009). Therefore, hepatic uptake after calving appears to be the major source of intracellular carnitine.

Role of PPARQ in Molecular Adaptations. Data from nonruminant studies clearly demonstrate that NEFA taken up by the liver bind and activate the PPAR $\alpha$ signaling pathway (Kersten et al., 1999); PPAR is a transcription regulator that plays a central role in the metabolic adaptations to dietary energy deficiency. Moreover, the agonistic role of LCFA in bovine cells and a recent review of the literature in ruminants has led to the hypothesis that upregulation of PPARA and its target genes (ACOX1, CPT1A, HMGCS2, $A C A D V L)$ when circulating NEFA concentrations increase will help to coordinate LCFA oxidation and ketogenesis (Bionaz et al., 2013). Although PPARA expression did not differ between wh 1 and 3 among treatments, the differences in the expression pattern of target genes such as HMGCS2 and ACOX1 (which are transcriptionally regulated) in HBCS and MBCS cows, along with circulating NEFA and BHBA levels, provide some evidence that they may work through LCFA activation of PPAR. Changes in the expression of PPARA in liver around calving have not always been recorded (Bionaz et al., 2013). One study even reported no hepatic change in PPARA expression in cows with ketosis and high plasma NEFA and when cows were fed LCFA beginning in the dry period (Carriquiry et al., 2009). The longitudinal decrease in expression of CPT1A (all groups) and IGFBP1 (except LBCS), both well-established PPAR $\alpha$ targets (Degenhardt et al., 2006) in nonruminants (Bionaz et al., 2013), indicates that they are not strict PPAR $\alpha$ targets or that alternate mechanisms play a role in controlling their expression in ruminants (e.g., intracellular malonyl-CoA, hepatic insulin sensitivity). Future work in this area is warranted.

Gluconeogenesis. The fact that cows in HBCS and MBCS had greater $P C$ and $P D K 4$ during the first 3 wk postcalving is indicative of an adaptation to support greater rates of gluconeogenesis for the higher milk production in those cows. In fact, expression of $P C$ generally increases during the transition to lactation and during feed restriction (Greenfield et al., 2000; Velez and Donkin, 2005; Loor et al., 2006) to allow, in periods of NEB, pyruvate carbon to be channeled through oxaloacetate to maintain hepatic glucose output (Reynolds et al., 2003). In addition, the higher expression of $P D K 4$ after calving limits the oxidation of pyruvate in the TCA cycle to increase its availability for gluconeogenesis (Sugden and Holness, 2003).

\section{BCS at Calving and Hepatokine Expression as Metabolic Stress Signals}

The induction of hepatic FGF21 expression stimulates hepatic oxidation of LCFA and gluconeogenesis in response to fasting and during consumption of a ketogenic diet (Domouzoglou and Maratos-Flier, 2011). In TMR-fed cows, Schoenberg et al. (2011) reported a positive relationship between energy deficit and plasma fibroblast growth factor 21 (FGF21) concentration, coupled with greater hepatic mRNA expression. Calving increases circulating concentration of growth hormone and glucagon as part of the homeorhetic adaptations 
to lactation, and both have been recognized as regulating hepatic expression of FGF21, either via direct activation or, indirectly, via the activation of PPAR $\alpha$ by NEFA (Uebanso et al., 2011). All the groups had changes over time in FGF21 and ANGPTL4, another hepatokine controlled by PPAR $\alpha$ (Kersten et al., 2000), that were similar to those of $P C$ and $P D K 4$ (not in LBCS), reflecting a concerted mechanistic adaptation linking LCFA oxidation and gluconeogenesis.

The increased hepatic expression of hepatokines in the HBCS cows after calving agrees with Khan et al. (2014), particularly the data from cows overfed energy during the dry period. Although BCS after calving were not reported by Khan et al. (2014), similar studies from the same research group (Graugnard et al., 2012, 2013) detected higher BCS precalving in energy-overfed cows. In contrast to hepatic mRNA expression, Khan et al. (2014) detected a greater serum concentration of FGF21 in control cows, which suggests the existence of intra- or extrahepatic mechanisms, or both, that help control systemic FGF21 concentrations. Despite the lack of blood FGF21 in the present study, we speculate a similar type of effect in MBCS and HBCS cows; that is, both had more pronounced increases in NEFA and BHBA, suggesting that the greater FGF21 expression ("local effect") helped attenuate oxidation of fatty acids and ketogenesis.

The fact that expression of FGF21 and ANGPTL4 was greater in the HBCS cows underscores the more pronounced NEB status (Roche et al., 2013). Both hepatokines could be used as blood biomarkers of energy balance during the peripartal period. Their potential role in regulation of adipose tissue lipolysis and insulin sensitivity (Murata et al., 2013; Nakamura et al., 2014) also suggests they could provide information about the degree of metabolic stress and potentially be used as a measure of susceptibility to metabolic disorders. For instance, ANGPTL4 (angiopoietin-like 4) increases in both nonruminants (Lu et al., 2010) and early postcalving cows when challenged with a proinflammatory stimulus (LPS; Graugnard et al., 2013). This suggests a possible role of circulating ANGPTL4 and FGF21 as APP reflecting metabolic stress, and their application as biomarkers should undergo further investigation.

\section{BCS at Calving and Inflammatory and Oxidative Stress Responses}

The acute-phase response (APR) is a complex earlydefense system, initiated by proinflammatory cytokines released from macrophages and monocytes at the site of infection or tissue damage (Bertoni and Trevisi, 2013). Serum albumin generally decreases during the APR and is, therefore, considered a major negative APP (Bertoni and Trevisi, 2013). Fat infiltration in the liver also may affect the concentration of some blood components, including albumin. Albumin concentrations among all groups were greater than reported pathological levels (Bertoni et al., 2008). Nevertheless, the overall pattern was suggestive of a lower inflammatory response after calving for the HBCS and MBCS cows than for the LBCS group. The lesser response to the expression of $A L B$ in HBCS compared with MBCS cows between 1 and 3 wk was surprising, because postcalving serum albumin levels did not differ between these groups and was markedly lower in the LBCS cows. Because low plasma albumin concentration is generally considered an indicator of chronic proinflammatory liver activation (Bertoni and Trevisi, 2013), independently from circulating concentrations, the $A L B$ mRNA expression patterns suggest that the HBCS and MBCS groups could have differed in their proinflammatory status. Such differences could be related to the greater influx of NEFA or accumulation of TAG in the HBCS group; however, further research is warranted.

Body condition score affected the concentration of serum HP but had no effect on SAA; however, their patterns around calving were typical of what is commonly reported in dairy cattle (Bertoni and Trevisi, 2013). The greater expression of $H P$ and $S A A 3$ in wk 1 in the MBCS cows compared with HBCS suggests a more pronounced inflammatory state, but the marked decrease in expression of both APP by wk 3 postpartum suggests this was limited to a transient adaptation associated with parturition and lactogenesis.

It is noteworthy that the molecular data do not seem to be associated with the temporal concentrations of AST, GGT, and GDH, which are commonly used as biomarkers of hepatocyte damage and overall health (Bertoni and Trevisi, 2013). In contrast, a high concentration of globulin, as detected in the HBCS group, would be indicative of poor liver function (Bertoni et al., 2008); when combined, the AGR supports the notion that cows in HBCS (and LBCS) had compromised liver function compared with MBCS. It must be noted, however, that postcalving concentrations of globulin were below those reported for cows with signs of inflammation-related liver dysfunction (Bertoni et al., 2008).

Haptoglobin and SAA are positive APP that can act as antioxidant and antiinflammatory agents, at least in part by regulating the maturation and activity of immune cells. Their expression is regulated by the NFKBSTAT3 signaling pathway (class II acute phase genes; Burgess-Beusse and Darlington, 1998). The greater mRNA expression in wk 1 of NFKB1 and STAT3 along with $H P$ and $S A A 3$ in the MBCS group was surprising and suggests that a transient inflammatory status 
within the liver is not necessarily associated with poor liver function (e.g., high serum AGR and albumin) and lower milk production. This idea is partly supported by the greater expression of NFKB1 and $S A A 3$ in wk 3 in the LBCS cows compared with MBCS. Furthermore, accumulation of TAG in liver did not seem to compromise the ability of cows to produce more milk or promote a sustained proinflammatory response within liver. These represent novel findings and seem to confirm that some degree of inflammation is part of the homeorhetic mechanisms coordinating the transition into lactation (Bertoni et al., 2004; Farney et al., 2013). However, as our data also suggest, a sustained proinflammatory response is not desirable and in the long term could compromise the ability of the cows to reach their potential for milk production (Bertoni et al., 2004). The present data from LBCS cows supports this point.

To conclude, our results highlight the effects of differing calving BCS on measures of production, inflammatory state, and metabolism. Cows calving at BCS 3.5 or 5.5 were compromised relative to cows calving at BCS 4.5 (1-10 scale). Collectively, the results support a similar optimum calving BCS for pasture-based dairy cows to that recommended by Roche et al. (2009). This optimum calving BCS is approximately BCS 5.0 (i.e., equivalent to BCS 3.0 in a 5 -point scale).

\section{ACKNOWLEDGMENTS}

The authors acknowledge the significant support of Alan Napper and Jessica Morse (DairyNZ, Hamilton, New Zealand) for on-farm logistics; Bruce Sugar and the DairyNZ Lye Dairy Farm team for their management and care of animals; and Stu Morgan, Kate Watkins, Kirsty McLeod, Nicola Priest, Viliami Taufa, and Mark Bryant (DairyNZ) for technical support. The COMSATS Institute of Information and Technology (Pakistan) and National Institute of Food and Agriculture (NIFA, Washington, DC; project ILLU-538-914) provided funds for Haji Akbar to conduct this work during his doctoral degree. This project was funded by the Ministry for Business, Innovation, and Employment (contract numbers C10X0813 and UoAX0814) and New Zealand dairy farmers through DairyNZ Inc. (contract numbers AW805, AW806, AN808, and AN1202).

\section{REFERENCES}

Agenäs, S., E. Burstedt, and K. Holtenius. 2003. Effects of feeding intensity during the dry period. 1. Feed intake, body weight, and milk production. J. Dairy Sci. 86:870-882.

Bernabucci, U., B. Ronchi, N. Lacetera, and A. Nardone. 2005. Influence of body condition score on relationships between metabolic status and oxidative stress in periparturient dairy cows. J. Dairy Sci. 88:2017-2026.

Bertoni, G., and E. Trevisi. 2013. Use of the liver activity index and other metabolic variables in the assessment of metabolic health in dairy herds. Vet. Clin. North Am. Food Anim. Pract. 29:413-431.

Bertoni, G., E. Trevisi, X. Han, and M. Bionaz. 2008. Effects of inflammatory conditions on liver activity in puerperium period and consequences for performance in dairy cows. J. Dairy Sci. 91:3300-3310.

Bertoni, G., E. Trevisi, and F. Piccioli-Cappelli. 2004. Effects of acetyl-salicylate used in post-calving of dairy cows. Vet. Res. Commun. 28(Suppl. 1):217-219.

Bewley, J. M. S. 2008. Review: An interdisciplinary review of body condition scoring for dairy cattle. Prof. Anim. Sci. 24:507-529.

Bionaz, M., S. W. Chen, M. J. Khan, and J. J. Loor. 2013. Functional role of PPARs in ruminants: Potential targets for fine-tuning metabolism during growth and lactation. PPAR Res. 2013:684159.

Boisclair, Y. R., R. P. Rhoads, I. Ueki, J. Wang, and G. T. Ooi. 2001 The acid-labile subunit (ALS) of the $150 \mathrm{kDa}$ IGF-binding protein complex: an important but forgotten component of the circulating IGF system. J. Endocrinol. 170:63-70.

Bremer, J. 1983. Carnitine-metabolism and functions. Physiol. Rev. 63:1420-1480.

Burgess-Beusse, B. L., and G. J. Darlington. 1998. C/EBPalpha is critical for the neonatal acute-phase response to inflammation. Mol. Cell. Biol. 18:7269-7277.

Busato, A., D. Faissler, U. Kupfer, and J. W. Blum. 2002. Body condition scores in dairy cows: Associations with metabolic and endocrine changes in healthy dairy cows. J. Vet. Med. A Physiol. Pathol. 49:455-460.

Carlson, D. B., J. W. McFadden, A. D'Angelo, J. C. Woodworth, and J. K. Drackley. 2007. Dietary L-carnitine affects periparturient nutrient metabolism and lactation in multiparous cows. J. Dairy Sci. 90:3422-3441.

Carriquiry, M., W. J. Weber, S. C. Fahrenkrug, and B. A. Crooker. 2009. Hepatic gene expression in multiparous Holstein cows treated with bovine somatotropin and fed n-3 fatty acids in early lactation. J. Dairy Sci. 92:4889-4900.

Dann, H. M., N. B. Litherland, J. P. Underwood, M. Bionaz, A. D'Angelo, J. W. McFadden, and J. K. Drackley. 2006. Diets during far-off and close-up dry periods affect periparturient metabolism and lactation in multiparous cows. J. Dairy Sci. 89:3563-3577.

Degenhardt, T., M. Matilainen, K. H. Herzig, T. W. Dunlop, and C. Carlberg. 2006. The insulin-like growth factor-binding protein 1 gene is a primary target of peroxisome proliferator-activated receptors. J. Biol. Chem. 281:39607-39619.

Doepel, L., G. E. Lobley, J. F. Bernier, P. Dubreuil, and H. Lapierre. 2009. Differences in splanchnic metabolism between late gestation and early lactation dairy cows. J. Dairy Sci. 92:3233-3243.

Domouzoglou, E. M., and E. Maratos-Flier. 2011. Fibroblast growth factor 21 is a metabolic regulator that plays a role in the adaptation to ketosis. Am. J. Clin. Nutr. 93:901S-905S.

Drackley, J. K. 1999. ADSA Foundation Scholar Award: Biology of dairy cows during the transition period: The final frontier? J. Dairy Sci. 82:2259-2273.

Eaton, S. 2002. Control of mitochondrial beta-oxidation flux. Prog. Lipid Res. 41:197-239.

Farney, J. K., L. K. Mamedova, J. F. Coetzee, B. KuKanich, L. M. Sordillo, S. K. Stoakes, J. E. Minton, L. C. Hollis, and B. J. Bradford. 2013. Anti-inflammatory salicylate treatment alters the metabolic adaptations to lactation in dairy cattle. Am. J. Physiol. Regul. Integr. Comp. Physiol. 305:R110-R117.

Gillund, P., O. Reksen, Y. T. Grohn, and K. Karlberg. 2001. Body condition related to ketosis and reproductive performance in Norwegian dairy cows. J. Dairy Sci. 84:1390-1396.

Graugnard, D. E., M. Bionaz, E. Trevisi, K. M. Moyes, J. L. SalakJohnson, R. L. Wallace, J. K. Drackley, G. Bertoni, and J. J. Loor. 2012. Blood immunometabolic indices and polymorphonuclear neutrophil function in peripartum dairy cows are altered by level of dietary energy prepartum. J. Dairy Sci. 95:1749-1758. 
Graugnard, D. E., K. M. Moyes, E. Trevisi, M. J. Khan, D. Keisler, J K. Drackley, G. Bertoni, and J. J. Loor. 2013. Liver lipid content and inflammometabolic indices in peripartal dairy cows are altered in response to prepartal energy intake and postpartal intramammary inflammatory challenge. J. Dairy Sci. 96:918-935.

Greenfield, R. B., M. J. Cecava, and S. S. Donkin. 2000. Changes in mRNA expression for gluconeogenic enzymes in liver of dairy cattle during the transition to lactation. J. Dairy Sci. 83:1228-1236.

Grum, D. E., J. K. Drackley, R. S. Younker, D. W. LaCount, and J. J. Veenhuizen. 1996. Nutrition during the dry period and hepatic lipid metabolism of periparturient dairy cows. J. Dairy Sci. 79:1850-1864.

Hayirli, A., R. R. Grummer, E. V. Nordheim, and P. M. Crump. 2002 Animal and dietary factors affecting feed intake during the prefresh transition period in Holsteins. J. Dairy Sci. 85:3430-3443.

Kersten, S., S. Mandard, N. S. Tan, P. Escher, D. Metzger, P. Chambon, F. J. Gonzalez, B. Desvergne, and W. Wahli. 2000. Characterization of the fasting-induced adipose factor FIAF, a novel peroxisome proliferator-activated receptor target gene. J. Biol. Chem. 275:28488-28493.

Kersten, S., J. Seydoux, J. M. Peters, F. J. Gonzalez, B. Desvergne, and W. Wahli. 1999. Peroxisome proliferator-activated receptor alpha mediates the adaptive response to fasting. J. Clin. Invest. 103:1489-1498.

Khan, M. J., C. B. Jacometo, D. E. Graugnard, M. N. Corrêa, E. Schmitt, F. Cardoso, and J. J. Loor. 2014. Overfeeding dairy cattle during late-pregnancy alters hepatic PPAR $\alpha$-regulated pathways including hepatokines: Impact on metabolism and peripheral insulin sensitivity. Gene Regul. Syst. Bio. 8:97-111.

Lacetera, N., D. Scalia, U. Bernabucci, B. Ronchi, D. Pirazzi, and A. Nardone. 2005. Lymphocyte functions in overconditioned cows around parturition. J. Dairy Sci. 88:2010-2016.

Litherland, N. B., H. M. Dann, and J. K. Drackley. 2011. Prepartum nutrient intake alters palmitate metabolism by liver slices from peripartal dairy cows. J. Dairy Sci. 94:1928-1940.

Loor, J. J., H. M. Dann, N. A. Guretzky, R. E. Everts, R. Oliveira C. A. Green, N. B. Litherland, S. L. Rodriguez-Zas, H. A. Lewin, and J. K. Drackley. 2006. Plane of nutrition prepartum alters hepatic gene expression and function in dairy cows as assessed by longitudinal transcript and metabolic profiling. Physiol. Genomics $27: 29-41$.

Lu, B., A. Moser, J. K. Shigenaga, C. Grunfeld, and K. R. Feingold. 2010. The acute phase response stimulates the expression of angiopoietin like protein 4. Biochem. Biophys. Res. Commun. 391:1737-1741.

Matthews, L. R., C. Cameron, A. J. Sheahan, E. S. Kolver, and J. R. Roche. 2012. Associations among dairy cow body condition and welfare-associated behavioral traits. J. Dairy Sci. 95:2595-2601.

Murata, Y., K. Nishio, T. Mochiyama, M. Konishi, M. Shimada, H. Ohta, and N. Itoh. 2013. Fgf21 impairs adipocyte insulin sensitiv- ity in mice fed a low-carbohydrate, high-fat ketogenic diet. PLoS ONE 8:e69330.

Nakae, J., Y. Kido, and D. Accili. 2001. Distinct and overlapping functions of insulin and IGF-I receptors. Endocr. Rev. 22:818-835.

Nakamura, M. T., B. E. Yudell, and J. J. Loor. 2014. Regulation of energy metabolism by long-chain fatty acids. Prog. Lipid Res. 53:124-144.

Reynolds, C. K., P. C. Aikman, B. Lupoli, D. J. Humphries, and D. E. Beever. 2003. Splanchnic metabolism of dairy cows during the transition from late gestation through early lactation. J. Dairy Sci. 86:1201-1217.

Roche, J. R., and D. P. Berry. 2006. Periparturient climatic, animal, and management factors influencing the incidence of milk Fever in grazing systems. J. Dairy Sci. 89:2775-2783.

Roche, J. R., P. G. Dillon, C. R. Stockdale, L. H. Baumgard, and M. J. VanBaale. 2004. Relationships among international body condition scoring systems. J. Dairy Sci. 87:3076-3079.

Roche, J. R., N. C. Friggens, J. K. Kay, M. W. Fisher, K. J. Stafford, and D. P. Berry. 2009. Invited review: Body condition score and its association with dairy cow productivity, health, and welfare. J. Dairy Sci. 92:5769-5801.

Roche, J. R., K. A. Macdonald, K. E. Schutz, L. R. Matthews, G. A. Verkerk, S. Meier, J. J. Loor, A. R. Rogers, J. McGowan, S. R. Morgan, S. Taukiri, and J. R. Webster. 2013. Calving body condition score affects indicators of health in grazing dairy cows. J. Dairy Sci. 96:5811-5825.

Schlegel, G., J. Keller, F. Hirche, S. Geissler, F. J. Schwarz, R. Ring seis, G. I. Stangl, and K. Eder. 2012. Expression of genes involved in hepatic carnitine synthesis and uptake in dairy cows in the transition period and at different stages of lactation. BMC Vet. Res. 8:28.

Schoenberg, K. M., S. L. Giesy, K. J. Harvatine, M. R. Waldron, C. Cheng, A. Kharitonenkov, and Y. R. Boisclair. 2011. Plasma FGF21 is elevated by the intense lipid mobilization of lactation. Endocrinology 152:4652-4661.

Sugden, M. C., and M. J. Holness. 2003. Recent advances in mechanisms regulating glucose oxidation at the level of the pyruvate dehydrogenase complex by PDKs. Am. J. Physiol. Endocrinol. Metab. 284:E855-E862.

Uebanso, T., Y. Taketani, H. Yamamoto, K. Amo, H. Ominami, H Arai, Y. Takei, M. Masuda, A. Tanimura, N. Harada, H. Yamanaka-Okumura, and E. Takeda. 2011. Paradoxical regulation of human FGF21 by both fasting and feeding signals: Is FGF21 a nutritional adaptation factor? PLoS ONE 6:e22976.

Velez, J. C., and S. S. Donkin. 2005. Feed restriction induces pyruvate carboxylase but not phosphoenolpyruvate carboxykinase in dairy cows. J. Dairy Sci. 88:2938-2948. 